\title{
Anatomy of Fascial Canal of Great Saphenous Vein: An Observational Study
}

\section{ABSTRACT}

Introduction: The fascial canal for great saphenous vein has a variable presence throughout the course of the vein. The anatomy of great saphenous vein and its tributary becomes complicated owing to interruptions and variability of the saphenous fascia around the knee compared with the upper portion of thigh and lower portion of leg. It has been observed that vein not enclosed in saphenous fascial canal is prone to have dilatations which can lead to varicosity of the vein.

Aim: To study the length and extent of fascia of great saphenous vein in 10 male and five female cadavers by macroscopic and microscopic observation. And also to note the length of great saphenous vein in thigh and leg.

Materials and Methods: An observational cadaveric study was done in which 10 male and five female cadavers were obtained and superficial dissection was performed in order to expose the Great Saphenous Vein (GSV) and its fascia. The lower limb was divided into eight equal quadrants and sample was taken from each quadrant for microscopic examination to confirm presence of saphenous fascia.

Results: In present study, there was absence of fascia in 30 lower limb (13.33\%) in whole length of great saphenous vein. There was no case in which the fascia extended throughout the length of great saphenous vein. No fascial canal was found in the lowermost quarter of leg.

Conclusion: Knowledge of the presence of saphenous fascia is essential while performing endovenous ablation. The utility of compression therapy and extent of compression needed may vary depending upon the presence or absence of saphenous fascia around great saphenous vein.

\section{INTRODUCTION}

The word saphenous is derived from the Greek word safaina, the feminine form of the adjective safes, which means evident. In order to have a clear understanding of the anatomy and relationship of superficial vein, one should have a thorough knowledge about the fascial layers and compartments of lower limb [1]. The muscular fascia surrounding the muscles of lower limb divide the lower limb into two compartments; one lying above the muscular fascia and beneath the skin is the superficial compartment. The other compartment is located beneath the muscular fascia and is called deep compartment. The deep compartment has muscles and deep veins. The veins of lower limb depending upon their location can be divided into three systems: 1) the superficial veins are situated beneath the skin and above muscular fascia. These are responsible for cutaneous microcirculation; 2) the deep veins are located deep to the muscular fascia. These veins drain the muscles of lower extremity; 3) the perforating veins are the connecting veins which penetrate the muscular fascia in order to connect superficial veins with the deep veins. They have valves in order to have unidirectional flow of blood from superficial to deep veins. The saphenous vein along with its tributaries is situated in the superficial compartment.

Saphenous fascia is thinner as compared to muscular fascia and is a membranous layer of subcutaneous tissue overlying the saphenous veins. Both saphenous and muscular fascia appears hyperechogenic on ultrasound. These two fasciae form a saphenous compartment whose roof is formed by saphenous fascia and floor is formed by muscular fascia. The two fasciae unite on either side to form a closed space in which lies the saphenous vein [1]. The GSV being the longest vein of the body begins distally as a continuation of the medial marginal vein of foot and drains in the femoral vein a short distance below the inguinal ligament [2]. The saphenous nerve is the largest and longest cutaneous branch of femoral nerve. It is closely related to GSV distal to the knee and is located in the saphenous fascia in this region [2]. The saphenous compartment contains only the GSV or its duplicate. The tributaries and other accessory veins of GSV are located outside the saphenous compartment. On ultrasound, the hyper-echogenicity of the saphenous fascia and muscular fascia and situated in between these two fasciae is the saphenous vein: which is hypoechogenic, results in a sign called 'Egyptian eye sign' or the 'ultrasonographic eye sign'. [3-5]. In the transverse, scan saphenous compartment appears to be like an eye in which lumen of saphenous vein is the iris, saphenous fascia being the upper eyelid and muscular fascia the lower eyelid. The fascia surrounding Great Saphenous Vein (GSV) and Small Saphenous Vein (SSV) have same terminology i.e., saphenous fascia. The saphenous fascia is found to be well formed in upper thigh and lower leg region. The anatomy of saphenous vein and its tributaries becomes complicated due to the variable presence of saphenous fascia around the knee as compared to upper region of thigh and lower region of leg. A thorough knowledge of variability of saphenous fascia is required by clinicians when performing endovenous ablative therapy [6]. The presence or absence of fascia over GSV decides the use of compression therapy and the extent of compression needed. This study has been carried out to look for the anatomy of great saphenous vein and its fascia in fresh cadavers along with its histological study and to appreciate its possible role in the pathogenesis of varicosities of great saphenous vein.

\section{MATERIALS AND METHODS}

The present study was an observational study conducted between July 2015 to July 2017.

Inclusion criteria: Inclusion criteria for the study were undissected adult cadavers obtained from Anatomy department and unclaimed adult cadavers from Forensic Department with both the lower limbs intact.

Exclusion criteria: Cadavers having any visible malformation or deformities in lower limb.

In a period of two years, 15 cadavers (10 male and 5 female), were obtained following inclusion criteria. All adults more than 18 years were dissected at the Department of Anatomy and Forensic 
Medicine and anatomy of great saphenous vein and fascia was studied [Table/Fig-1]. The ethical clearance was obtained from Institute of Medical Sciences, Banaras Hindu University, Varanasi. (No. Dean/15-16/CAEC). The great saphenous vein was exposed by performing a superficial dissection from its origin at the medial end of dorsal venous arch till the area where it drains into femoral vein i.e., saphenofemoral junction, located short distance distal to inguinal ligament [7]. A thorough observation of its tributaries and perforators were also done. Photographs of the vein were taken and any variations if present, were noted [Table/Fig-2-4]. The great saphenous vein was ligated proximally at the saphenofemoral junction and distally anterosuperior to the medial malleolus. The length of GSV in thigh was measured between two surface marking points i.e., from location of saphenofemoral junction which is 3-4 cm below and lateral to pubic tubercle [8] to the medial femoral epicondyle. In the leg, it was measured between medial femoral epicondyle to the upper ridge of medial malleolus. The course of the vein was divided into eight equal quadrants (four quadrants in each thigh and leg). This division of lower limb into quadrant
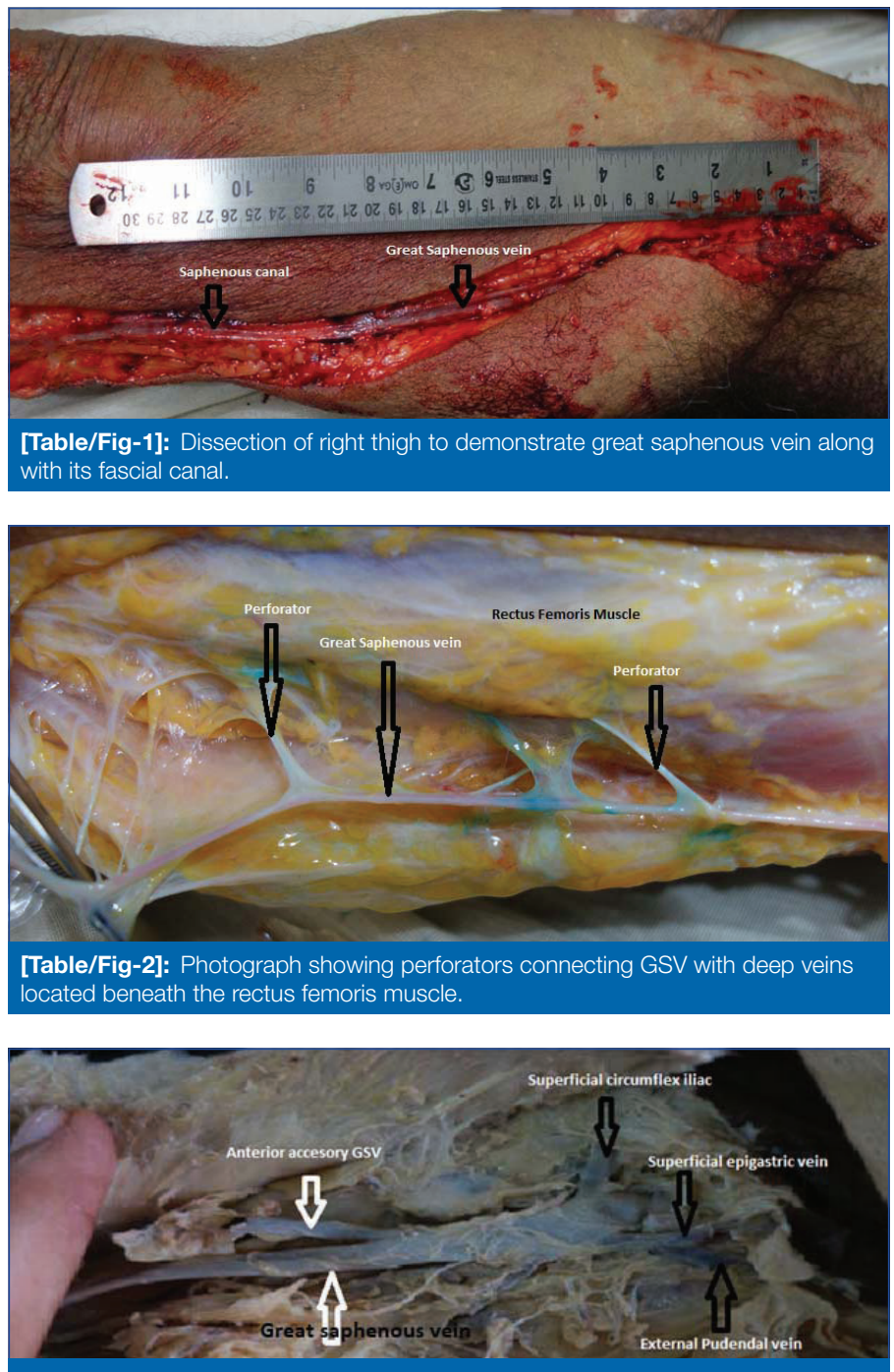

[Table/Fig-3]: Photograph showing saphenofemoral junction and its tributaries namely superficial epigastric vein, superficial circumflex iliac vein and external pudendal vein. Anterior accessory great saphenous vein along with great saphenous vein can also be seen.

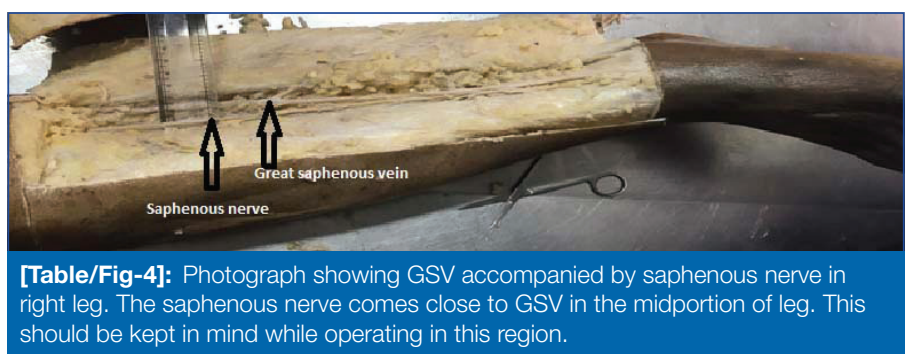

was performed in order to know the frequency of occurrence of saphenous fascia in different quadrants. The saphenous fascia was carefully observed and its extent was accurately measured by means of a measuring tape. It appeared as a translucent sheath over the vein. Histological specimens were taken for presence of saphenous fascia from each quadrant of lower limb. The samples were preserved in $10 \%$ formalin. The examination of saphenous fascia was done. Samples were fixed in $4 \%$ paraformaldehyde overnight. After fixation, the samples were dehydrated with serial grade of $30 \%, 50 \%, 70 \%, 90 \%$ and absolute alcohol. Samples were kept in xylene for 5 minutes for clearing and then embedded in paraffin wax. Section of $3 \mu \mathrm{m}$ thickness were cut and spread on glass slide. Staining was done by fast green modification of Von Gieson stain [Table/Fig-5].

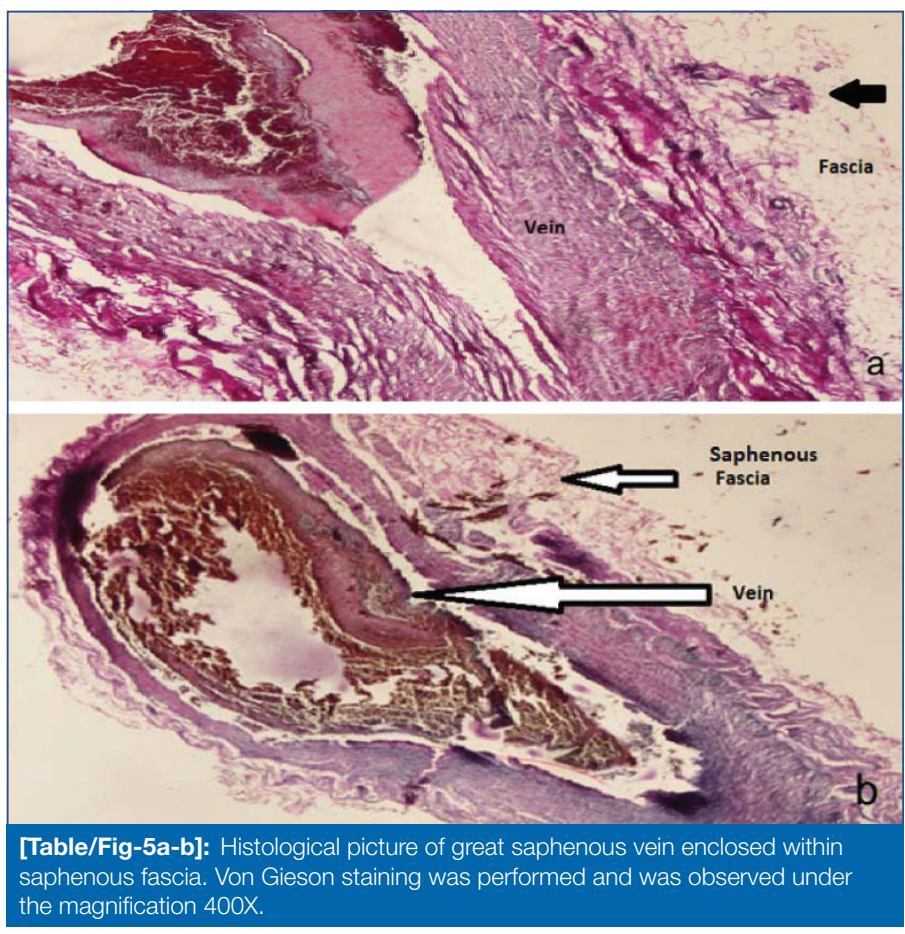

Following aspects were observed:

1. Length of GSV in thigh and leg;

2. Length of fascial canal in thigh and leg;

3. Comparison of length of GSV in male and female;

4. Comparison of length of saphenous canal in male and female;

5. Extent of saphenous canal.

\section{STATISTICAL ANALYSIS}

All the data was entered in Microsoft excel sheet and was analysed by means of Statistical Package For The Social Sciences (SPSS) software trial version 21. Chi-square test was used. The $p$-value $<0.05$ considered as statistically significant.

\section{RESULTS}

The length of GSV in thigh and leg was $32.78 \pm 2.012 \mathrm{~cm}$ and $31.71 \pm 1.982 \mathrm{~cm}$, respectively [Table/Fig-6].

\begin{tabular}{|l|c|c|c|c|}
\hline Parameters & $\begin{array}{c}\text { Number of } \\
\text { cadavers }\end{array}$ & $\begin{array}{c}\text { Minimum } \\
\text { length }(\mathbf{c m})\end{array}$ & $\begin{array}{c}\text { Maximum } \\
\text { length }(\mathbf{c m})\end{array}$ & $\begin{array}{c}\text { Mean } \pm \text { Standard } \\
\text { deviation }(\mathbf{c m})\end{array}$ \\
\hline GSV thigh & 15 & 31 & 37 & $32.78 \pm 2.012$ \\
\hline GSV leg & 15 & 30 & 36 & $31.71 \pm 1.982$ \\
\hline $\begin{array}{l}\text { Length of fascial } \\
\text { canal in thigh }\end{array}$ & 15 & 0 & 24 & $19.87 \pm 8.107$ \\
\hline $\begin{array}{l}\text { Length of fascial } \\
\text { canal in leg }\end{array}$ & 15 & 0 & 22 & $14.54 \pm 9.408$ \\
\hline
\end{tabular}

[Table/Fig-6]: Length of Great Saphenous Vein (GSV) and its fascia canal were measured in 15 cadavers ( 10 male and 5 female). 
The length of GSV in thigh and leg in male was $(33.46 \pm 2.049 \mathrm{~cm})$ and $(32.35 \pm 2.033 \mathrm{~cm})$, respectively whereas in female it was $(31.44 \pm 1.155 \mathrm{~cm})$ and $(30.42 \pm 1.147 \mathrm{~cm})$, respectively. Comparison of length of GSV in male and female cadavers was analysed. The p-values of length of GSV in thigh and leg were found to be 0.064 and 0.072 by using Chi-square test. Both the values were statistically insignificant.

The length of fascial canal in thigh of male was $22.80 \pm 1.304 \mathrm{~cm}$ while in female it was $18.40 \pm 9.712$. In leg, the length of fascial canal in male was that of $15.11 \pm 10.437 \mathrm{~cm}$ and in female was of $13.40 \pm 7.893 \mathrm{~cm}$. Comparison of length of saphenous canal in male and female cadaver was analysed. The p-value of length of saphenous canal of GSV in thigh and leg were found to be 0.340 and 0.416 by using Chi-square test. Both the values were statistically insignificant.

Out of 30 lower limbs, only 2 (6.6\%) had saphenous canal around the vein in first quadrant of thigh. No fascial canal was found in the $4^{\text {th }}$ quadrant of vein in leg. There was no case found in which fascial canal was found extending from $1^{\text {st }}$ quadrant of thigh to $4^{\text {th }}$ quadrant of leg [Table/Fig-7].

\begin{tabular}{|l|c|c|}
\hline Extent of saphenous canal & $\begin{array}{c}\text { Frequency (out of } \\
30 \text { lower limbs) }\end{array}$ & $\begin{array}{c}\text { Percentage } \\
\text { (30 lower limbs) }\end{array}$ \\
\hline Present in $1^{\text {st }}$ quadrant of vein in thigh & 2 & 6.6 \\
\hline Present in $2^{\text {nd }}$ quadrant of vein in thigh & 24 & 80 \\
\hline Present in $4^{\text {th }}$ quadrant of vein in thigh & 20 & 66.7 \\
\hline Present in $3^{\text {rd }} 4^{\text {th }}$ quadrant of vein in thigh & 20 & 66.7 \\
\hline Present in first quadrant of vein in leg & 20 & 66.7 \\
\hline Present in $1^{\text {st }}-2^{\text {nd }}$ quadrant of vein in leg & 20 & 66.7 \\
\hline Present $1^{\text {st }}, 2^{\text {nd }}-3^{\text {rd }}$ quadrant of vein in leg & 4 & 13.3 \\
\hline Fascial canal in $4^{\text {th }}$ quadrant of leg & 0 & 0 \\
\hline \\
[Table/Fig-7]: Study of extent of saphenous canal in various quadrants of lower \\
limb showing the frequency and percentage of presence of saphenous fascia in \\
30 lower limbs (10 male and five female).
\end{tabular}

\section{DISCUSSION}

The anatomists and surgeons have different beliefs regarding the fascia; while the anatomists are of opinion that there are two types of fascia namely superficial and deep; surgeons still believe deep fascia as to be the only fascia. The superficial fascia is composed of a layer of loose areolar connective tissue or adipose tissue located immediately under the skin [9]; whereas deep fascia is formed of dense connective tissue situated beneath the superficial fascia and binds the muscles and tendon underneath. At some places like around saphenous veins, this dense connective tissue can be found in the superficial fascia forming a separate fascia called saphenous fascia $[10,11]$. In present study, there was no case in which the fascial canal was found to extend from $1^{\text {st }}$ quadrant of vein in thigh to $4^{\text {th }}$ quadrant of vein in leg. The fascial canal was found to be absent in the fourth quadrant of leg in all the cases. This finding was comparable to study of Papadopoulos NJ et al., who also divided the lower limb into eight equal quadrants to observe the presence of fascia in each quadrant [10].

In present study, in $13.33 \%$ cases fascia was absent in the whole length of great saphenous vein which is slightly lower as compared to study of Papadopoulos $\mathrm{NJ}$ et al., who reported it in 15\% cases [10]. [Table/Fig-8] shows comparison of the length of GSV in thigh and leg and length of fascial canal in thigh and leg from previous study [10]. The mean value of length of GSV in thigh and leg was found to be lower as compared to the previous study. On the other hand, fascial canal was found to extend more as compared to the previous study. This may be due to the differences in the genetic factors, body constitution, geographical conditions, feeding habits and the better socioeconomic status, in the western countries where this study was done. The frequency of presence of saphenous canal in present study was found to be higher in all quadrants except $1^{\text {st }}$ quadrant of thigh as compared to study by Papadopoulos NJ et al., [10]. No fascial canal was found in fourth quadrant of leg in the present and previous study.

\begin{tabular}{|c|c|c|}
\hline Parameters & $\begin{array}{l}\text { Papadopoulos NJ et } \\
\text { al.,1981 [10] (Range } \\
\text { given and Mean } \\
\text { mentioned in bracket) }\end{array}$ & $\begin{array}{l}\text { Present study (Range } \\
\text { given, mean and } \\
\text { standard deviation } \\
\text { mentioned in bracket) }\end{array}$ \\
\hline Length of GSV in leg $(\mathrm{cm})$ & $\begin{array}{l}31-37 \mathrm{~cm}(34.5 \mathrm{~cm}) \\
34.9 \mathrm{~cm} \text { in males } \\
33.2 \mathrm{~cm} \text { in females }\end{array}$ & $\begin{array}{c}30-36 \mathrm{~cm}(32.35 \pm 2.033) \\
\text { in males } \\
30-32 \mathrm{~cm}(30.42 \pm 1.147) \\
\text { in females }\end{array}$ \\
\hline $\begin{array}{l}\text { Length of GSV in thigh } \\
\text { (cm) }\end{array}$ & $\begin{array}{l}30-37 \mathrm{~cm}(34 \mathrm{~cm}) \\
34.6 \mathrm{~cm} \text { in males } \\
33.2 \mathrm{~cm} \text { in females }\end{array}$ & $\begin{array}{c}31-37 \mathrm{~cm}(33.46 \pm 2.049) \\
\text { in males } \\
31-34 \mathrm{~cm}(31.44 \pm 1.155) \\
\text { in females }\end{array}$ \\
\hline $\begin{array}{l}\text { Total Length of GSV } \\
\text { (in } \mathrm{cm} \text { ) }\end{array}$ & $\begin{array}{c}61-74 \mathrm{~cm}(68.6 \mathrm{~cm}) \\
\text { Mean of } 69.5 \mathrm{~cm} \text { in males } \\
\text { Mean of } 67.1 \mathrm{in} \text { females }\end{array}$ & $\begin{array}{l}60.26-67.5 \mathrm{~cm}(64.49) \\
\text { Mean of } 65.8 \text { in males } \\
\text { Mean of } 61.9 \text { in females }\end{array}$ \\
\hline $\begin{array}{l}\text { Length of fascial canal in } \\
\text { thigh }(\mathrm{cm})\end{array}$ & $5-32 \mathrm{~cm}(16.76 \mathrm{~cm})$ & $\begin{array}{c}0-24 \mathrm{~cm}(22.80 \pm 1.304) \\
\text { in males } \\
0-24 \mathrm{~cm}(18.40 \pm 9.712) \text { in } \\
\text { females }\end{array}$ \\
\hline $\begin{array}{l}\text { Length of fascial canal in } \\
\text { leg }(\mathrm{cm})\end{array}$ & $4-20 \mathrm{~cm}(9.46 \mathrm{~cm})$ & $\begin{array}{c}0-22 \mathrm{~cm}(15.11 \pm 10.437) \\
\text { in males } \\
0-21 \mathrm{~cm}(13.40 \pm 7.893) \text { in } \\
\text { females }\end{array}$ \\
\hline $\begin{array}{l}\text { Frequency of saphenous } \\
\text { canal in first quadrant in } \\
\text { thigh (percentage) }\end{array}$ & 5 & 6.6 \\
\hline $\begin{array}{l}\text { Frequency of saphenous } \\
\text { canal in second quadrant } \\
\text { of thigh (percentage) }\end{array}$ & 38.3 & 80 \\
\hline $\begin{array}{l}\text { Frequency of saphenous } \\
\text { canal in third quadrant of } \\
\text { thigh (percentage) }\end{array}$ & 35.0 & 66.7 \\
\hline $\begin{array}{l}\text { Frequency of saphenous } \\
\text { canal in fourth quadrant } \\
\text { of thigh (percentage) }\end{array}$ & 3.3 & 66.7 \\
\hline $\begin{array}{l}\text { Frequency of saphenous } \\
\text { canal in first quadrant of } \\
\text { leg (percentage) }\end{array}$ & 31.6 & 66.7 \\
\hline $\begin{array}{l}\text { Frequency of saphenous } \\
\text { canal in second quadrant } \\
\text { of leg (percentage) }\end{array}$ & 26.7 & 66.7 \\
\hline $\begin{array}{l}\text { Frequency of saphenous } \\
\text { canal in third quadrant of } \\
\text { leg (percentage) }\end{array}$ & 3.3 & 13.3 \\
\hline $\begin{array}{l}\text { Frequency of saphenous } \\
\text { canal in fourth quadrant } \\
\text { of leg (percentage) }\end{array}$ & 0 & 0 \\
\hline \multicolumn{3}{|c|}{$\begin{array}{l}\text { [Table/Fig-8]: Comparison of length of great saphenous vein and fascial canal } \\
\text { with previous study [10]. } \\
\text { GSV: Great saphenous vein }\end{array}$} \\
\hline
\end{tabular}

Caggiati A proposed that the possibility of varicose veins is reduced in areas where the veins are situated inside the saphenous canals [12]. Caggiati A (2000) pointed out the tributaries of saphenous vein which lie outside the saphenous canal are prone to develop dilatation [13]. Labropoulus $\mathrm{N}$ et al., have reported incidence of dilatations of vein is more in tributaries and accessory veins than the main trunk of great saphenous vein [14]. Fascial canal gives to the wall of vein more resistance to the hydrostatic pressures of the blood, thus it reduces possibility of development of varicosity of the vein, provided that, there no other factors such as incompetent valves or deep thrombosis [15]. Fascial canal is absent at various lengths and there is a possibility, that varicose burst may occur through the veins which are not covered by fascial canal. This canal is variable in length and is absent at several places. Probably one of the etiologies of varicose veins may be the absence of fascial canal from where varicosity arises. 


\section{Limitation(s)}

This study was done on 10 male and five female cadavers which account to be a small sample size. An ultrasonographic study involving more number of normal subjects as well as subjects with varicose veins is necessary.

\section{CONCLUSION(S)}

It is essential for the clinicians to have knowledge about variations in presence of fascial canal around the great saphenous vein while doing any operative procedures such as endovenous ablation on the patients or creating ankle fistula between great saphenous vein and dorsalis pedis artery in case of haemodialysis patients.

\section{REFERENCES}

[1] Caggiati A. Fascial relationships of the long saphenous vein. Circulation. 1999;100:2547-49.

[2] Standring S. Gray's Anatomy. 39 $9^{\text {th }}$ ed. London: Elsevier Churchill Livingstone; 2005. Pp. 1452-53.

[3] Cavezzi A, Labropoulos N, Partsch H, Myers K, Nicolaides A, Cavezzi A. Duplex ultrasound investigation of the veins in chronic venous disease of the lower limbs-UIP consensus document. Part II. Anatomy. Eur J Vasc Endovasc Surg. 2006;31:288-99.
[4] Ricci S, Georgiev M. Ultrasound anatomy of the superficial veins of the lower limb. J Vasc Technol. 2002;26:183-99.

[5] Mendoza E, Lattimer CR, Morrison N (edltors). Duplex Ultrasound of Superficial veins. Springer Berlin Heidelberg 2014 Pp. 93.

[6] Joh JH, Kim WS, Jung IM, Park KH, Lee T, Kang JM, et al. Consensus for the treatment of varicose vein with radiofrequency ablation. Vasc Specialist Int. 2014;30(4):105-12.

[7] Vijaywargiya M, Jain M, Devpujari R. Morphological variations in duplication of great saphenous vein. J Evolution Med Dent Sci. 2016;5(59):4052-55.

[8] Mirjalili SA, Muirhead JC, Stringer MD. Redefining the surface anatomy of the saphenofemoral junction in vivo. Clin Anat. 2014;27(6):915-19.

[9] Benjamin M. The fascia of the limbs and back-a review. J Anat. 2009;214(1):01-18.

[10] Papadopoulos NJ, Sherif MF, Albert EN. A fascial canal for the great saphenous vein: Gross and microanatomical observations. J Anat. 1981;132(Pt 3):321-29.

[11] Shah AC, Srivastava HC. Fascial canal for the small saphenous vein. J Anat. 1966;100(Pt 2):411-13

[12] Caggiati A. The saphenous venous compartments. Surg Radiol Anat 1999;21:29-34.

[13] Caggiati A. Fascial relations and structure of the tributaries of the saphenous veins. Surg Radiol Anat. 2000;22:191-96.

[14] Labropoulos N, Kokkosis AA, Spentzouris G, Gasparis AP, Tassiopoulos AK. The distribution and significance of varicosities in the saphenous trunks. J Vasc Surg. 2010;51(1):96-103.

[15] Meissner $\mathrm{MH}$. Lower extremity venous anatomy. Semin Intervent Radiol. 2005;22(3):147-56. Doi: 10.1055/s-2005-921948.

\section{PARTICULARS OF CONTRIBUTORS:}

1. Assistant Professor, Department of Anatomy, Institute of Medical Sciences, Varanasi, Uttar Pradesh, India.

2. Senior Resident, Department of Surgery, Institute of Medical Sciences, Varanasi, Uttar Pradesh, India.

3. Associate Professor, Department of Surgery, Institute of Medical Sciences, Varanasi, Uttar Pradesh, India.

4. Professor, Department of Forensic Medicine, Institute of Medical Sciences, Varanasi, Uttar Pradesh, India.

5. Professor, Department of Surgery, Institute of Medical Sciences, Varanasi, Uttar Pradesh, India.

NAME, ADDRESS, E-MAIL ID OF THE CORRESPONDING AUTHOR:

Dr. Soumya Khanna,

Assistant Professor, Department of Anatomy, IMS, BHU,

Varanasi-221005, Uttar Pradesh, India.

E-mail: khannasoumya15@gmail.com

\section{AUTHOR DECLARATION:}

- Financial or Other Competing Interests: None

- Was Ethics Committee Approval obtained for this study? Yes

- Was informed consent obtained from the subjects involved in the study? NA

- For any images presented appropriate consent has been obtained from the subjects. NA
PLAGIARISM CHECKING METHODS: [Jain $\mathrm{H}$ et al.]

- Plagiarism X-checker: Jul 11, 2020

- Manual Googling: Dec 10, 2020

- iThenticate Software: Feb 20, 2021 (9\%)
ETYMOLOGY: Author Origin

Submission: Jul 10, 2020

Date of Peer Review: Sep 12, 2020

Date of Acceptance: Dec 31, 2020

Date of Publishing: Jul 01, 2021 